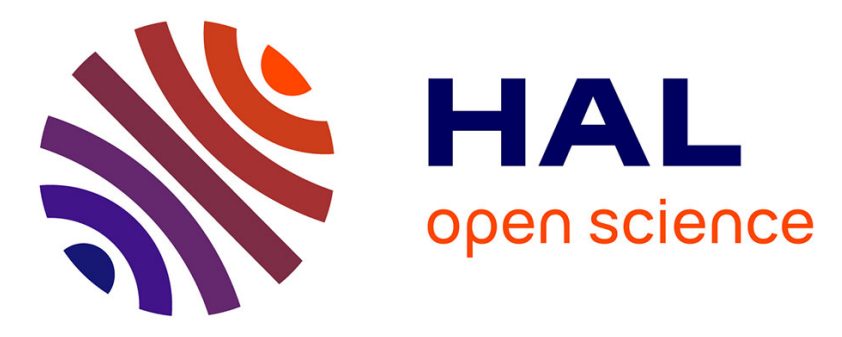

\title{
Genetics to the rescue: managing forests sustainably in a changing world
}

\author{
Bruno Fady, Filippos Aravanopoulos, Raquel Benavides, Santiago \\ González-Martínez, Delphine Grivet, Martin Lascoux, Marcus Lindner, \\ Christian Rellstab, Fernando Valladares, Barbara Vinceti
}

\section{To cite this version:}

Bruno Fady, Filippos Aravanopoulos, Raquel Benavides, Santiago González-Martínez, Delphine Grivet, et al.. Genetics to the rescue: managing forests sustainably in a changing world. Tree Genetics and Genomes, 2020, 16 (6), pp.80. 10.1007/s11295-020-01474-8 . hal-03013862

\section{HAL Id: hal-03013862 \\ https://hal.inrae.fr/hal-03013862}

Submitted on 19 Nov 2020

HAL is a multi-disciplinary open access archive for the deposit and dissemination of scientific research documents, whether they are published or not. The documents may come from teaching and research institutions in France or abroad, or from public or private research centers.
L'archive ouverte pluridisciplinaire HAL, est destinée au dépôt et à la diffusion de documents scientifiques de niveau recherche, publiés ou non, émanant des établissements d'enseignement et de recherche français ou étrangers, des laboratoires publics ou privés.

\section{(c)(1)}

Distributed under a Creative Commons Attribution| 4.0 International License 


\title{
Genetics to the rescue: managing forests sustainably in a changing world
}

Authors: Fady B, Aravanopoulos P, Benavides R, González-Martínez SC, Grivet D, Lascoux M, Lindner M, Rellstab C, Valladares F, Vinceti B.

Author for correspondence. Dr. Bruno Fady, INRAE Avignon, France bruno.fady@inrae.fr

This is the preprint of a published paper that can be cited as:

Fady B., Aravanopoulos F., Benavides R., González-Martínez S., Grivet D., Lascoux M., Lindner M., Rellstab C., Valladares F., Vinceti B., 2020. Genetics to the rescue: managing forests sustainably in a changing world. Tree Genetics \& Genomes, 16(6), 1-11 (https://doi.org/10.1007/s11295-020-01474-8).

\begin{abstract}
There is growing concern that the implementation of political agreements on climate change and biodiversity will not be enough to protect forests in the short run and up to the end of the 21 st century. As mitigation efforts are lagging behind self-imposed, reasonable targets, genetic diversity will have a large and significant part to play in the process of adapting forests to climate change. Genetic diversity, the raw material of evolution, can be used for adaptation by natural selection and artificial breeding, in naturally regenerated and plantation forests alike. The two-day scientific conference: "\#rescueforests: Genetics to the rescue - Managing forests sustainably in a changing world", addressed the genetic diversity of forests. More specifically, the conference was about natural as well as assisted adaptive processes, their spatial scale, from fine grain to landscape and ecoregions, and how much of the genome it involves. It also dealt with phenotypes and how much of their variation is determined by underlying genetic diversity. And finally, and perhaps most importantly, the conference emphasized the importance of conservation and sustainable use of this genetic diversity as a nature-based solution to adapt under the fast pace of climate change. The conference demonstrated how improved knowledge on genomic diversity and evolutionary mechanisms can help to rescue forests, either naturally or by means of management.
\end{abstract}

\section{Keywords}

Genomic diversity, environment, phenotype, conservation, breeding, policy.

Funding: This publication is part of a project that has received funding from the European Union's Horizon 2020 research and innovation programme under grant agreement No. 676876 (GenTree). 


\section{Introduction}

There is growing concern that the implementation of political agreements on climate change and biodiversity will not be enough to protect forests in the short run and up to the end of the 21st century (Brown et al. 2019). Looking at the current trend of carbon emissions, we are on the path to $+3^{\circ} \mathrm{C}$ global temperature increase since the beginning of the industrial revolution, far from the goals set by the Paris agreement in 2015 (Plumer and Popovich 2018). As mitigation efforts are lagging behind selfimposed targets, genetic diversity has a large and significant part to play in the process of adapting forests to climate change (Alfaro et al. 2014). Genetic diversity is the raw material upon which evolution can act; and this raw material can be used for adaptation by natural selection and artificial breeding alike. In this respect, genetic diversity represents a nature-based solution for adapting forests and forestry to climate change while preserving biodiversity (Eggermont et al. 2015).

The two-day conference: "\#rescueforests: Genetics to the rescue - Managing forests sustainably in a changing world", held in Avignon (France) January 2020, addressed how genomic, phenotypic, and spatial data across diverse species can be leveraged to understand the distribution of existing genetic variation and to assess the adaptive capacity of populations. The conference explored new tools in conservation and breeding designed to maintain species' evolutionary potential.

The conference focused on natural as well as assisted adaptive processes, their spatial scale, from fine grain to landscape and ecoregions, and how much of the genome it involves. It also dealt with phenotypic variation and how much of it is determined by underlying genetic diversity. And finally, and perhaps most importantly, the conference emphasized the importance of conservation, breeding and sustainable management of genetic diversity. As it is unclear whether long-lived forest trees (normally exhibiting long generation times) can keep up with the fast pace of climate change (Aitken et al. 2008), the conference focused on how genetic diversity and evolutionary mechanisms can help rescue forests, either naturally or by means of management. Results were then discussed during a one-day stakeholder consultation co-organized with the European program EUFORGEN, immediately following the scientific conference. Stakeholders focused on the identification of critical issues not yet addressed by research, on the formulation of a list of research priorities for future collaborative work in the area of forest genetic resources conservation and sustainable use, and on the preparation of a portfolio of research ideas to be presented to international, EU and national funding agencies and implementing agencies (Annex 1).

The conference included four sessions, with substantial contributions stemming from the H2020 project GenTree (Pennisi 2020), the organizer of the event. All talks were filmed, professionally edited and the videos made available on two platforms (Annex 2). Most posters were also made available by their authors (Annex 2). The takehome messages of each session and the conference in general are outlined in the conclusion and emphasized in Figure 1. 


\section{1- Genomes and the environment}

Variation in phenotypic and fitness traits is the result of a complex interplay between environment and genome. Disentangling the relative roles of environment and genetic variation in shaping past and present phenotypic variation is therefore crucial to be able to predict the effect of future climate change or to characterize the genetic architecture of quantitative traits. Historically, such investigations have been mainly performed with common garden experiments, where individuals from different provenances are exposed to the same natural or manipulated environment, thus highlighting genetic differences among provenances (Savolainen et al. 2013). Additionally, reciprocal transplant experiments, combining several common gardens in the local habitats of the populations, have been used to demonstrate local adaptation and describe various relationships between environment, genotype, and phenotype (e.g. Ågren and Schemske 2012). While such approaches have been very valuable to test the performance of different ecotypes in different environments (e.g. Alberto et al. 2013), they are not able to make inferences about the molecular mechanisms underlying adaptation and the genomic architecture of trait variation.

Genomic approaches have started to fill this gap. Recent technical developments in genome sequencing and analytical advances have led to new possibilities to describe genome-wide patterns, especially for the study of environmental adaptation. Pairing high-resolution environmental datasets (e.g. Karger et al. 2017) alongside genomic data provides the opportunity to perform tests for selection via Fst outlier analysis (Hohenlohe et al. 2010), quantify genome-environment associations (Rellstab et al. 2015), and perform gene diversity analyses (Hohenlohe et al. 2010).

From a more polygenic perspective, it has been shown that under certain scenarios, coordinated and minor changes at a large number of loci better explain the pattern of local adaptation than large allele frequency changes at a few individual loci (Berg and Coop 2014; Le Corre and Kremer 2012, Yeaman 2015). While such approaches have been applied on genome-wide scale in model species for quite some time already (e.g. Hancock et al. 2011), they were limited in forest trees due to their massive genome size and complexity. However, this has recently changed due to dropping sequencing costs, the development of reduced representation sequencing/genotyping approaches (e.g. Bamshad et al. 2011), and the publication of several reference genome assemblies (e.g. Mosca et al. 2019).

Building upon the rich history of provenance trials and population genetics, genomics has pushed the field of forest genetics forward to study adaptation to the environment and uncover the molecular basis of fitness-relevant traits. However, many open questions remain, such as: How can we best combine provenance trails and genomics to study environmental adaptation? How polygenic are molecular mechanisms behind adaptation? To what extent are tree populations maladapted to current conditions or may be in the future under climate change? How has demographic history shaped contemporary adaptation? How convergent is adaptation among tree species? This session included a selection of talks and posters that addressed these challenging questions.

Antoine Kremer (INRAE, France) opened the session with a keynote on how contemporary selection shapes oak phenotypes. His talk mainly concentrated on the 
Petite Charnie State Forest in western France (Truffaut et al. 2017), where his team has, over many years, repeatedly sampled and genotyped a mixed oak stand consisting of Quercus robur and $Q$. petraea, allowing them to reconstruct pedigrees. Results show that Quercus petraea had a much larger phenotypic and genetic variance of fitness than $Q$. robur. The investigations suggest that $Q$. robur will probably decline steadily over time, particularly in mixed stands with $Q$. petraea, consistent with the contrasting demographic dynamics of the two species. This keynote impressively showed that it takes a long time to build the required experimental and genomic resources for thorough studies on selection at the local level.

The session was continued by Ulaszewski Bartosz (Kazimierz Wielki University, Poland) who examined continent-wide population structure in European beech (Fagus sylvatica). He identified three distinct clusters that seem to overlap potential glacial refugia and postglacial migration routes. Interestingly, the spatial genetic structure was identical when using either neutral or only putatively adaptive loci. Tanja Pyhäjärvi (University of Oulu, Finland) then looked at the genetic architecture of clinal local adaptation in Scots pine, Pinus sylvestris. Based on a large-scale sampling, she pointed out the need for more attention towards multi-locus analysis of polygenic adaptation and to the importance of haplotype inversions, which is little studied in forest trees, despite their major potential impact on phenotypes. Finally, Pascal Milesi (Uppsala University, Sweden) tackled the topic of genetic architecture of fitness-relevant traits in Norway Spruce (Picea abies) and identified both rather oligo- (bud burst) and polygenic (growth) controlled traits. Connecting two studies (Chen et al. 2019; Milesi et al. 2019), he illustrated how evolutionary biologists can take advantage of the resources in breeding programs to investigate the evolutionary and demographic history of species and dissect the genetic basis of local adaptation.

The second part of the session continued with talks that presented data of the GenTree project. First, Martin Lascoux (Uppsala University, Sweden) showed how modern genomic approaches - in this case targeted sequence capture - allows the re-interpretation of population genetic structure in terms of past demographic and climatic events, and how the paired sampling design of Lotterhos and Whitlock (2015) used in GenTree will enhance adaptation genomic analyses. Katharina Budde (INRAE Pierroton, France) was interested in the range-wide genetic structure of maritime pine (Pinus pinaster). She first used haploid tissue sequencing and the method of McKinney et al. (2017) to identify paralogous, multi-copy gene regions found in the targeted capture sequences of carried out for the GenTree project. With the resulting, stringently filtered dataset, she identified marginal populations of conservation interest in southeastern France, Portugal, southern Morocco and Tunisia. The session was concluded by Benjamin Dauphin (WSL, Switzerland) who showed that adaptation to climate and soil is highly polygenic in European beech $(F$. sylvatica) and sessile oak (Q. petraea). Interestingly, whereas the strongest signal of selection in beech was found with precipitation-related bioclimatic factors, it was with temperature-related factors in oaks.

The session also included five posters, ranging from bioinformatics pipelines (AnnaMaria Farsakoglou, University of Thessaloniki, Greece) to the description of demographic and adaptive patterns of tree species in Europe (Scots pine expansion in Europe by Chedly Kastally, University of Oulu, Finland, and adaptive landscape 
of European beech by Meredith Schuman, University of Zurich, Switzerland) and in North and South America (Local adaptation of Nothofagus pumilio in the Andes by Jill Sekely, Marburg University, Germany, and spatial genetic differentiation in Picea glauca stands of Alaska by Melanie Zacharias, University of Greifswald, Germany).

\section{2- Local adaptation of climate change related traits}

Climate change and related processes (e.g. forest fires and outbreaks of new pests and diseases) impose a strong selective pressure on natural ecosystems. Although forest trees have survived numerous past climatic oscillations, the unprecedented current speed of change raises concerns about their ability to migrate and, most of all, adapt locally (Aitken et al. 2008). There is lack of evidence for rapid adaptation for most species and environments, and the role of genes with major effect on adaptive traits is still not well-known. In addition, only few phenotypic traits have been studied in forest trees that are relevant for increased forest resilience and health.

The keynote of Andrew J. Eckert (Virginia Commonwealth University, USA) showed how the old questions about adaptation can be re-evaluated with new data and methods (Bower and Aitken 2008). Firstly, combining provenance trial data with a genomic approach, he showed that, in sugar pine (Pinus lambertiana), whitebark pine $(P$. albicaulis) and Western white pine ( $P$. monticola), local adaptation can occur at very fine scale (Eckert et al. 2015; Lind et al. 2017), and evidenced that gene flow does not (always) preclude local adaptation. Secondly, he showed that adaptive responses rely on polygenic adaptation with subtle and coordinated allele frequency differences (Le Corre and Kremer 2012, Lind et al. 2017, Lind et al. 2018). Finally, he demonstrated that exogenous selection affects genetic diversity through hybridization, and that local adaptation can be fostered by adaptive introgression (Menon et al. 2017).

This session also included other contributions that can be grouped into three types of approaches. The first one included the study of geographical patterns of performance and phenotypic variation surveying in situ populations. Phenotypic traits often exhibit an optimum associated with local environments (Leimu and Fischer 2008) combined to the individual use of resources and biotic interactions (McGill et al. 2006). Within species, traits may vary geographically as a response to gradients at different scales (Reichstein et al. 2014), and understanding these patterns across the species distribution is crucial to define management strategies in the changing environment. Large phenotypic trait datasets across species' distributions seem an excellent source to track the performance and phenotypic variation among populations within species. Elisabet Martínez-Sancho (and see poster by Lenka Slámová, WSL Switzerland) exemplified the use of a large database of tree-ring widths gathered within the GenTree project (Martínez-Sancho et al. 2020) to identify vulnerable regions for several forest tree species under future scenarios. Alexandre Changenet (INRAE, France) compiled mortality data of 19 major forest species from the National Forest Inventories of Spain, France and Germany. He found that tree mortality amount is patchily distributed across species ranges whereas mortality occurrence is higher in populations at the rear edges of species ranges, suggesting that drought is a main driver of mortality in forest trees. Posters by Nataliya 
Korolyova (Czech University of Life Sciences) and Valentin Journé (INRAE France) indicated that other processes, such as insect outbreak resistance or seed set are critical for resilience.

The second group of approaches used quantitative genetic studies in common gardens. Understanding how populations genetically differ and respond to climate at early-life stages is key to predict their ability to thrive under new environmental conditions (Castro et al. 2005, Lloret et al. 2009). José A. Ramírez-Valiente (INIA, Spain) presented the first results of a multi-site common garden experiment with seeds of $P$. sylvestris collected from eight populations across its European distribution. Sowing 24,000 seeds in four contrasting sites (Finland, Lithuania, Germany and Spain) and measuring emergence, survival, early growth and ontogenic changes, they found that regional climate imposed important selective pressure on this species along the latitudinal gradient driving genetic differentiation in traits related to fitness. Using a similar design and with similar results, Aida SoléMedina (INIA, Spain) further confirmed the evolutionary potential of early-life traits in Betula pendula populations across Europe.

Julie Gauzère (University of Edinburgh, UK), using a common garden of 2,300 $F$. sylvatica seedlings from 60 open-pollinated families originating from three stands along a short elevation gradient at the rear edge of the species distribution, provided evidence of local adaptation in phenological traits, despite high gene flow among sites (Richardson et al. 2014, Gauzere et al. 2016, 2020). She also highlighted the beneficial effect of long-distance pollen dispersal after just one reproductive episode in those differentiated traits, with higher genetic variance in immigrant offspring compared to local one. In this same line, Claire Godineau (University of Montpellier, France), using an individual-based quantitative genetic model inspired from Devaux and Lande (2008), showed that assortative mating increases genetic variance in global warming scenarios whereas random mating does not, allowing increased fitness advantage and better tracking of changing environments.

Results from provenance/progeny trials are also used for disentangling the contribution of genetic diversity and phenotypic plasticity to the population differentiation for functional traits and fitness. Using data from 38 common gardens in Europe and North Africa, including 380,000 individuals from three Pinus species ( $P$. pinaster, $P$. pinea and $P$. nigra), Natalia Vizcaíno-Palomar (INRAE France) found strong plastic responses for height growth to the climatic variability but no clear pattern across the species ranges. Additionally, the poster of Paul Zeltins (SILAVA, Latvia) showed a longitudinal pattern of differentiation, based on growth and stem quality, using progenies from 26 provenances of $B$. pendula aged 14 years, with eastern populations (from more continental conditions) performing better. The poster of Rosario Sierra-de-Grado (Univ. Valladolid, Spain), demonstrated that stem straightness in $P$. pinaster typically followed a strong provenance differentiation pattern. Finally, Ricardo Alía (INIA Spain) showed significant phenotypic selection within and among populations for height and leaf traits in a selection gradient study conducted with 1,300 $P$. pinaster individuals under two contrasting environments.

A final third group of approaches, all of them poster contributions, included the use of genetic analyses to unveil the genes or factors underlying trait adaptation/acclimation. Irene Cobo-Simón (Univ. Pablo de Olavide, Spain) found 
SNPs related to drought resilience in Abies pinsapo suggesting candidate genes involved in its drought adaptive capacity. Albin Lobo (Univ. Copenhagen, Denmark) explored epigenetic processes underlying phenotypic differentiation in Abies nordmanniana and found that higher temperatures during somatic embryogenesis triggered earlier budburst. Genotype-phenotype associations were also found for wood anatomic traits in $P$. abies (Patrick Fonti, WSL Switzerland), serotiny in $P$. halepensis (Bastien Romero, INRAE France) and leaf reflectance spectra (as a proxy of health status) in F. sylvatica (Lucienne de Witte, Applied Plant Biology, Switzerland).

\section{3- Conserving and using genetic diversity}

Technological and analytical advances provide an unprecedented glimpse at neutral and adaptive genomic regions, therefore allowing a more precise characterization of genetic diversity, benefiting the sustainable use of genetic resources. Novel strategies for the dynamic conservation and breeding of plant genetic resources taking into account the adaptive potential of populations, are around the corner. This session debated how future efforts in long-term ex-situ and in-situ conservation, monitoring, breeding and management of genetic resources, will integrate novel genomics approaches and the new insights they procure.

Genetic diversity plays a key role in the adaptation of species and populations to changing environment and should be incorporated into management, use and conservation of forest trees. The posters presented by Alex Baumel (Aix-Marseille University, France) on carob trees (Ceratonia siliqua), Błażej Wójkiewicz (Academy of Sciences, Poland) on black poplar (Populus nigra) and Darius Kavaliauskas (AWG, Germany) on European beech ( $F$. sylvatica) and silver fir (Abies alba), all identified threats to the evolution of population (e.g. genetic erosion, low effective population size) under environmental changes and called for both ex-situ and in-situ conservation actions.

Understanding the adaptive capacity of natural populations remains a major challenge. Christian Rellstab (WSL, Switzerland) showed that the genetic diversity of putatively adaptive loci declined with increasingly suitable conditions in Swiss stone pine (Pinus cembra, Dauphin et al. 2020). Implications for conservation involve the important discrimination between neutral and adaptive diversity, and the preservation of several large core populations as genetic conservation units since each one demonstrates low adaptive genetic diversity. Marginal populations, on the other hand, carry significant levels of adaptive diversity and are important for conservation. Following an experimental approach associating genotypes, physiological traits and contrasted environments, Charalambos Neophytou (FVA, Germany) postulated that relict oaks (Quercus spp.) on extremely dry sites are adapted to water shortage and could be a future source of forest reproductive material. Cathleen Petit-Cailleux (INRAE, France), following a modeling approach, demonstrated that water stress vulnerability (assessed via simulated carbon and water fluxes) varied across the range of European beech ( $F$. sylvatica) in Europe using the process-based model CASTANEA. They found that genotypes minimizing the risk of drought-induced mortality differed from those maximizing growth and that management that takes genetic variability into account, can reduce mortality. Finally, 
the poster of Oliver Reutimann (WSL, Switzerland) presented a molecular kit of 58 SNPs usable for taxonomic diagnostics and assessment of admixture levels in temperate European oaks (Quercus robur, Q. petraea, Q. pubescens), with applications for understanding hybridization dynamics in genetic monitoring and forest management (Reutimann et al. 2020).

As the speed of environmental change challenges the potential of forest species to adapt, the necessity of conserving their genetic resources becomes a challenge. The poster of Filippos Aravanopoulos (Univ. Thessaloniki, Greece) stressed the importance of the genomic, phenotypic and environmental tools and data provided by project GenTree for the characterization of the in-situ European forest gene conservation network (de Vries et al. 2015), assessing species in situ conservation status, prioritizing future genetic monitoring (sensu Aravanopoulos et al. 2015) and ex situ conservation planning. In another poster, the same authors showed significant acclimatization changes over two generations in F. sylvatica, concluding that epigenetic changes should be part of the genetic diversity monitoring process. The poster of Anđelina Gavranović (Forest Research Institute, Croatia), characterizing fructification patterns in $Q$. robur and F. sylvatica, underlined that the current absence or chronic irregularity of seed crop under climate change can seriously undermine gene conservation efforts. Moreover, the poster of Aurore Desgroux (INRAE, France) described the French forest tree gene conservation network, showing that it prioritizes in-situ dynamic conservation (where conservation units allow adaptation to gradual environmental change), and forest tree species with high economic or ecological value and identified threats, opening opportunities to include gene conservation targets within protected areas.

Under increased environmental threats, ex-situ conservation becomes mandatory. Sean Hoban (Morton Arboretum, USA) highlighted that, based on modeling and experimental results, the usual rules-of-thumb for minimum sample sizes applied (that 50 samples will capture alleles with $>5 \%$ frequency with a $95 \%$ probability), are inadequate for obtaining sufficient genetic representation, due to species differences in their genetics and life history characteristics (Hoban and Strand 2015). Different sampling designs can have the same level of efficacy, i.e. sampling few populations/many trees per population, or many populations/few trees per populations (Hoban et al. 2018) and sampling strategies should be tailored to the biology of the target species. Clare Trivedi (Kew Gardens, UK) presented the strategy of the UK National Tree Seed project (UKNTSP) for capturing genetic diversity in ex- situ collections of 75 species. In the frequent absence of detailed knowledge of species population genetics, modeling shows that random sampling or using biogeographic zones as proxy for genetic diversity and adaptation, perform equally well for capturing genetic diversity. Collecting more populations than trees and more trees than seeds per tree, the UKNTSP Fraxinus excelsior collections captured $>90 \%$ of all alleles of natural populations (Hoban et al. 2018) and $86 \%$ in Taxus baccata (Gargiulo et al. 2019).

Genomic selection tools can help to better consider inbreeding depression and the loss of favorable alleles, and new traits of interest and their potential trade-offs. They are becoming available in non-model forest trees. Ian MacLachlan (University of British Columbia, Canada) presented a method to summarize genomic data for polygenic traits and detecting the effects of selective breeding on climatically 
adaptive genotypes in lodgepole pine ( $P$. contorta) in Canada. Altogether, results show that relationships among genotypes, phenotypes and climate were maintained or strengthened among the selective breeding programs sampled, suggesting that among breeding zones the same assisted gene flow prescriptions are valid for both natural and selectively bred seedlings. Even so, the potential for trade-offs among traits due to substantial antagonistic pleiotropy was evident and should be carefully monitored as a potential source of climatically maladaptation in selectively bred seedlings. Erik Kjaer (University of Copenhagen, Denmark) showed that natural genetic variation for resistance, and heritability of susceptibility to European ash (Fraxinus excelsior) dieback were high (between 0.4-05), indicating the substantially high potential a breeding program may have to increase the future health of European ash forests. However, the poster of José Climent (INIA, Spain) showed that the potential for breeding may be limited in other cases. Comparing phenotypic traits (growth, water use efficiency, reproductive allocation) in $P$. halepensis seedlings grown on highly contrasted sites, they found no overall genetic changes at candidate SNPs from the GenTree project attributable to selection that could explain differences.

Concerned with the fact that breeding programs may under-sample natural population diversity, the poster of Ricardo Alía (INIA, Spain) tested the levels of genetic diversity using approx. ten thousand SNPs developed in the Gentree project in seven species with active breeding programs in Europe (Betula pendula, Picea abies, Pinus pinaster, P. halepensis, P. nigra, P. sylvestris and Populus nigra). While genetic diversity is not significantly reduced overall, marginal habitats tend to be under-represented and the authors recommended that breeding populations be enriched with new material to address future demands and increased resilience under climate change.

The poster of Mathieu Tiret (Uppsala University, Sweden) presented a modified version of one of the most famous methods to balance increased selection and genetic diversity, the optimal contribution selection (OCS), by introducing mating selection in the equations, indicating that compensatory mating accelerates the response to selection. The poster of Sara Abrahamsson (Skogforsk, Sweden), using simulations, revealed that by using an open pollinated strategy, the Betula pendula breeding program can maintain a higher effective population size than when using controlled pollination, but that more generations are needed to reach the same level of gain. The poster of Romane Guilbaud (INRAE Evry, France) showed that SNP arrays are now usable tools to improve breeding for production, resilience and diversity in economically important species in Europe such as Populus sp., Fraxinus $\mathrm{sp} ., P$. pinaster and $P$. pinea. Finally, the poster of Christophe Orazio (EFI, France) reporting the 565 responses from nine European countries to an online survey on adaptive tree breeding, showed that improved forest reproductive materials from breeding programs are perceived positively by the forest sector, including for adaptation to climate change, and should address a larger panel of species than currently. 


\section{4- Evolutionary management of forests}

Practice in conservation and sustainable use of forests needs to deal with environmental changes of uncertain magnitude and scale. Forest management responses should consider the diversity of forest community types and silviculture regimes, and how these interact with natural evolutionary processes (Fady et al. 2016). Forest management can contribute to speeding up adaptation of forests to changing environmental regimes, identifying locally relevant options, such as for example, fast rotation silviculture, assisted migration and use of improved forest reproductive materials (Bolte et al. 2009, Schelhaas et al. 2015, Lefèvre et al. 2012). This session discussed how consideration of evolutionary processes can and should be integrated into conservation and management practices, and combined with selection and planting of best-adapted forest reproductive material, suited to the expected future conditions of the planting site. Socio-economic implications of evolutionary management practices were also discussed.

With regard to conservation aspects, innovative approaches were presented. A demonstration was provided by James S. Borrell (Royal Botanic Gardens Kew, UK) who showed how genomic assessments can enable to map those populations to be targeted for genetic rescue, through enrichment of their genetic diversity via assisted gene flow. He illustrated the case of dwarf birch (Betula nana), probably one of the first species that moved back into the UK after the glaciation. Recently, a decline of this species was observed in Scotland. While genetic diversity is still sufficiently high, a risk of genetic loss was identified, with suitable habitats projected to shrink under future climate conditions. The genomic assessment of local adaptation informed a climate resilient assisted gene flow strategy. Similarly, Juan Pablo Jaramillo-Correa (University of Mexico, Mexico) indicated a promising avenue for implementing genomic monitoring in management and conservation programs of natural populations, particularly predicting the performance of introduced seedlings and in guiding assisted migration in species with poorly developed genomic resources. He evaluated the accuracy of genomic prediction for the management and conservation of small secluded natural tree populations of sacred fir (Abies religiosa) in Mexico to inform assisted migration efforts and counteract inbreeding depression under climate change.

Novel resources have been generated by the GenTree project to improve how priority populations of different species across Europe can be target for conservation. AnnaMaria Farsakoglou (Univ. Thessaloniki, Greece) reported on a massive data collection effort to quantify genome-wide genetic diversity and differentiation in 12 major European tree species (8 conifers and 4 deciduous species). Two different genome-wide sequencing technologies (SPET genotyping and targeted capture sequencing) helped to detect highly polymorphic populations with potential to become gene conservation units, vulnerable populations in need of conservation, and genetic traits associated with local adaptation to the environment. Further analysis of the data promises to shed light on adaptive processes, contributing to refine existing tools and strategies for conservation and management of forest genetic resources.

Further demonstrations of how improved approaches are used in conservation, monitoring and restoration were presented in several posters. They included new applications for fingerprinting of genetic diversity as a tool for conservation in Cyprus 
(Nicolas Eliades, Frederick University, Cyprus); the development and implementation of a forest genetic monitoring program in Slovenia (Hojka Kraigher, Forestry Institute, Sovenia); the network of forest gene conservation units established in Spain (Jose García del Barrio, INIA, Spain); the protection and restoration efforts targeting Taxus baccata in Poland, based on understanding of genetic variation (Monika Litkowiec, Kostrzyca Forest Gene Bank, Poland), the assessment of land use change impacts on ecological security in Russia (luliia Polevshchikova, Volga State University, Russia); and the influence of seedling traits on natural and artificial selection of Scots pine in Finland (Sonja Kujala, Natural Resources Institute Finland).

With regard to forest management, Sally Aitken (University of British Columbia, Canada) highlighted in her keynote speech how risk modelling could be refined by incorporating genetic traits and susceptibility to pathogens. She presented recent research revealing a slow pace in the evolution of North American conifers, although this finding is coupled with phenotypic and genomic evidence for local adaptation in these species to a wide range of climates, manifested in the high variation in climateassociated traits. Fall cold injury is critical for lodgepole pine and interior spruces. Douglas fir also showed strong local adaptation to cold. Phenotypic and genomic approaches revealed similar patterns of local adaptation, with the strongest signals for cold hardiness. Concerning the management options that could be implemented, the views of local stakeholders are increasingly examined. She presented surveys results that indicated high social acceptance for natural regeneration and breeding of local tree species, but also for assisted gene flow and assisted species migration. On the contrary, responses were not supportive of the introduction of non-native species.

Devrim Semizer-Cuming (FVA, Germany) provided some hope with regard to genetic management practices that could help contain European ash ( $F$. excelsior) dieback. She presented new results on the heritability of traits of Chalara ash dieback tolerance and tested how they can be spread through enrichment planting, in case studies established in Germany and Denmark. Mating patterns in Germany indicated that a large share of pollen was from natural local sources. However, the realized pollen dispersal distance recorded was longer than $3 \mathrm{~km}$. A negative effect of the disease susceptibility was found on regeneration success; this gives hope that future generations of this species will be more tolerant to ash dieback.

Evolution-oriented forest management was proposed as an important management strategy in semi-natural forests in Europe (87\% of the forest area in this region). Each thinning and harvesting intervention affects the remaining genetic diversity in a forest stand, and the choice of seed trees greatly influence the genetic composition of future stands. Evolution-oriented forest management needs to be grounded on demo-genetic models that link different disciplinary fields, from forest dynamics, quantitative genetics, to silviculture and the analyses of natural disturbances. François Lefèvre (INRAE Avignon, France) introduced a new demo-genetic simulation approach that enables to quantify how much genetic selection for growth can result from silviculture. The effects of various management practices on (i) growth, (ii) genetic quality and (iii) evolutionary potential of the stand could be compared, using the CAPSIS simulation platform (http://capsis.cirad.fr/capsis/help en/luberon2).

An open question related to managing forests in light of climate change is whether adaptation measures that have been identified over the years should be 
implemented, and whether they are still appropriate, considering the recent extreme events and climate induced disturbances. Marcus Lindner (EFI, Germany) discussed how forest genetic resource management to foster resilience to climate change, needs to consider the overall management context. He presented the results of a literature review on forest management practices, based on country narratives from 27 European countries. The review revealed a wide heterogeneity of situations. Most European forests have been established by natural regeneration or natural expansion of the forest cover, but current regional practices differ (e.g., regeneration by planting dominates in North and Central-East Europe, whereas natural regeneration is prevalent in other parts of Europe). The literature review, combined with an expert survey conducted in the frame of the Forest Europe process, and a further assessment of management choices of forest owners and managers (Vinceti et al., 2020), suggested that current and proposed future management approaches should be carefully evaluated using latest scientific evidence and contextual specificities.

Finally, the economic potential of investing in breeding forest material was explored by Hernán Serrano-León (EFI, France), simulating the financial performance at stand level in pine stands in Finland, Sweden and France. Despite large economic differences between cases, the investment in breeding material generally resulted in greater financial performance and higher financial stability against price fluctuations, with a potential mitigation of negative effects of unexpected changes in global wood markets. Reduced rotation ages also allowed a more flexible silvicultural response, reducing risks of exposure to natural disasters, uncertain future climatic and socioeconomic conditions.

\section{Conclusion and perspectives}

Despite the burden of often having to deal with large and complex genomes, it is now feasible to investigate local adaptation signatures with genomic methods in many, non-model forest trees. Sophisticated methods are now available and participants of the conference concluded that studies to come should explicitly differentiate between neutral and adaptive regions of the genome. A detailed understanding of neutral, demographic processes, which can significantly confound or mimic adaptation patterns, is warranted to understand the past, present and future responses of forests to environmental change. And thus, sustainably manage genetic diversity, whether for conservation or for breeding (Figure 1).

Despite advances made in combining genomic and environmental data to predict phenotypic variation there remain gaps in our understanding of the complex relationships underlying genotype and phenotype across environments. Assessing phenotypic variation is a prerequisite for understanding the imprints of selection. Due to the high costs associated to common gardens, they remain a comparatively rare and precious experimental design, particularly for species with currently low economic interest and at habitat margins.

Seed and seedling stage, short-term common gardens are key for understanding early stage local adaptation and are comparatively low cost. However, classical long- 
term common gardens should regain priority in research projects and large-scale management experiments, including marginal and peripheral populations and sites, of increased importance under climate change. The conference also illustrated the possibility of taking advantage of the phenotypic resources available in breeding programs and long-term inventories.

Figure 1 - A contribution of forest genetics and genomics to sustainable forest management. State of the art of research findings (yellow box, tree roots), opportunities (orange circles, tree trunk), and research frontiers (grey circles in the tree canopy) for forest genetics in the 2020s.

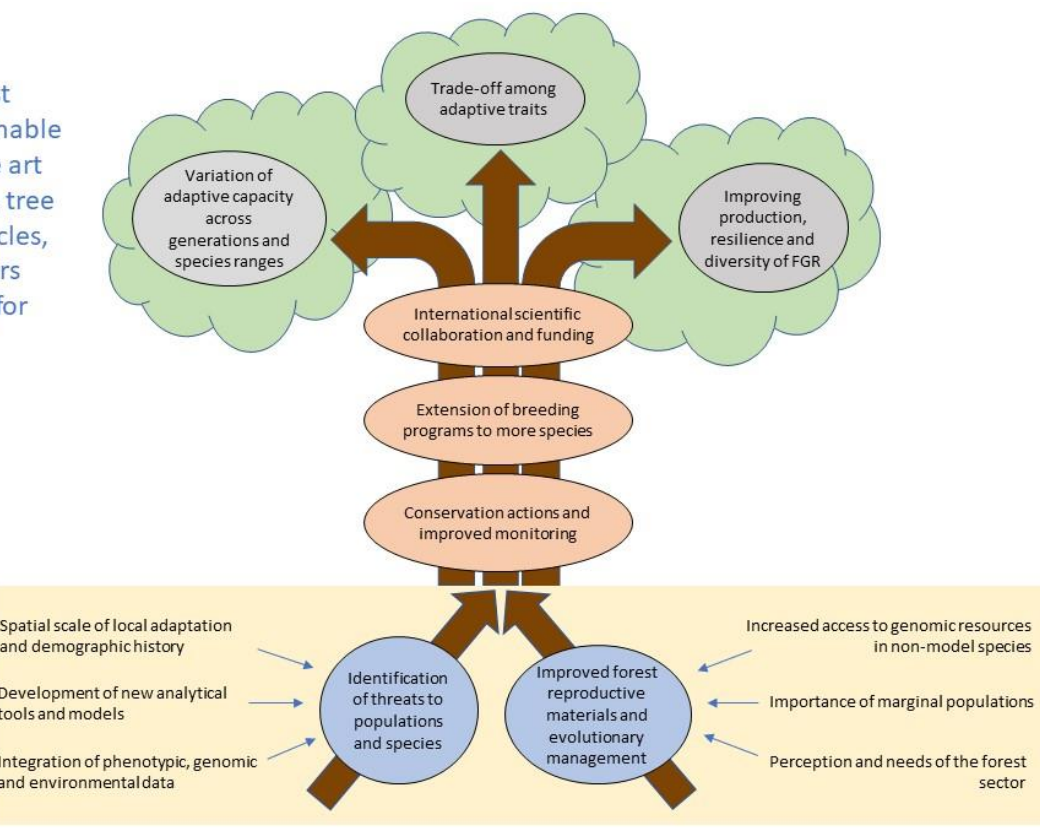

Most studies presented stressed the importance of integrating multidisciplinary approaches to better refine a species' adaptive capacity, including a comprehensive characterization of phenotypic, neutral and potentially adaptive genetic diversity, and particular for in situ and ex situ conservation, in breeding programmes and for implementing evolution-oriented forest management. The conference also made clear that the research field of forest genetics enormously profits from advances in environmental databases (mainly climate and soil), allowing accurate habitat characterization down to the resolution of single trees. Together with modern and high-throughput phenotyping methods, this will allow us to study the molecular mechanisms and environmental drivers of adaptation and to evaluate the risk of maladaptation of populations and species to ongoing and future environmental changes.

What remained as a challenge is to fully grasp and agree on what adaptive capacity (or potential) means for forest trees and forests, and how it can be benchmarked against potential use. Is it genetic diversity? Neutral or adaptive? Can a highly adapted population that shows reduced diversity, be characterized as having adaptive potential? Or can a population not demonstrating local adaption potentially adapt faster than a locally adapted population under quickly changing environmental conditions? Inferences made between genes, traits and the environment are clearly improving but accumulating phenotypic and environmental data at individual level also remains challenge. High throughput phenotypic data from reasonably well characterized local environments and a large number of individuals is the way 
forward, particularly for physiological traits related to biotic interactions and to drought resistance such as water balance and carbon storage. The use of multidisciplinary and process-based models will greatly help test hypotheses and resolve these challenges (Figure 1).

The conference \#rescueforest was a demonstration of innovative forest genetics science that can be used for management strategies. Genetic diversity is a naturebased solution for adapting forests to climate change that should definitely and urgently be used in both in plantation and naturally regenerated forests. It is also an old and lively field of research, to our great satisfaction. We hope that this report, and the resources it contains, will provide useful material for teaching, research group seminars and inspire future research.

\section{References}

Ågren J, Schemske DW, 2012. Reciprocal transplants demonstrate strong adaptive differentiation of the model organism Arabidopsis thaliana in its native range. New Phytologist 194: 1112-1122. doi:10.1111/j.1469-8137.2012.04112.x

Aitken SN, Yeaman S, Holliday JA, Wang TL, Curtis-McLane S, 2008. Adaptation, migration or extirpation: climate change outcomes for tree populations. Evolutionary Applications 1: 95-111.

Alberto FJ, Derory J, Boury C, Frigerio J-M, Zimmermann NE, Kremer A, 2013. Imprints of natural selection along environmental gradients in phenology-related genes of Quercus petraea. Genetics 195: 495-512. doi:10.1534/genetics.113.153783

Alfaro RI, Fady B, Vendramin GG, Dawson IK, Fleming RA, Sáenz-Romero C, Lindig-Cisneros RA, Murdock T, Vinceti B, Navarro CM, Skrøppa T, Baldinelli G, El-Kassaby YA, Loo J, 2014. The role of forest genetic resources in responding to biotic and abiotic factors in the context of anthropogenic climate change. Forest Ecology \& Management 333: 76-87.

Aravanopoulos FA, Tollefsrud MM, Graudal L, Koskela J, Kätzel R, Soto A, Nagy L, Pilipovic A, Zhelev P, Božic G, Bozzano M, 2015. Development of genetic monitoring methods for genetic conservation units of forest trees in Europe. European Forest Genetic Resources Programme (EUFORGEN), Bioversity International, Rome, Italy.

Avramidou EV, Ganopoulos IV, Doulis AG, Tsaftaris AS, Aravanopoulos F., 2015. Beyond population genetics: natural epigenetic variation in wild cherry (Prunus avium). Tree Genetics \& Genomes 11(5): 95. DOI 10.1007/s11295-015-0921-7.

Bamshad MJ, Ng SB, Bigham AW, Tabor HK, Emond MJ, Nickerson DA, Shendure J, 2011. Exome sequencing as a tool for Mendelian disease gene discovery. Nature Review Genetics 12: 745-755. doi:10.1038/nrg3031

Berg JJ, Coop G, 2014. A population genetic signal of polygenic adaptation PLOS Genetics 10: e1004412. doi:10.1371/journal.pgen.1004412

Bolte A, Ammer C, Löf M, Madsen P, Nabuurs GJ, Schall P, Spathelf P, Rock J, 2009. Adaptive forest management in central Europe: climate change impacts, strategies and integrative concept. Scandinavian Journal of Forest Research 24: 473-482. doi:10.1080/02827580903418224

Bower AD, Aitken SN, 2008. Ecological Genetics and Seed Transfer Guidelines for Pinus Albicaulis (Pinaceae). American Journal of Botany 95(1): 66-76

Brown C, Alexander P, Arneth A, Holman I, Rounsevell M, 2019. Achievement of Paris climate goals unlikely due to time lags in the land system. Nature Climate Change, 9(3): 203-208.

Castro J, Zamora R, Hódar JA, Gómez JM, 2005. Alleviation of summer drought boosts establishment success of Pinus sylvestris in a Mediterranean mountain: an experimental approach. Plant Ecology 181: 191-202.

Chen J, Li L, Milesi P, Jansson G, Berlin M, Karlsson B, Aleksic J, Vendramin GG, Lascoux M, 2019. Genomic data provide new insights on the demographic history and the extent of recent material transfers in Norway spruce. Evolutionary Applications 12: 1539-1551 doi:10.1111/eva.12801

Dauphin B, Wüest RO, Brodbeck S, Zoller S, Fischer MC, Holderegger R, . . Rellstab C, 2020. Disentangling the effects of geographic peripherality and habitat suitability on neutral and adaptive genetic variation in Swiss stone pine. Molecular Ecology, 29(11), 1972-1989. doi:10.1111/mec. 15467 
Devaux C, Lande R, 2008. Incipient allochronic speciation due to non-selective assortative mating by flowering time, mutation and genetic drift. Proceedings of the Royal Society B 275: 2723-2732

de Vries, S.M.G., Alan, M., Bozzano, M., Burianek, V., Collin, E., Cottrell, J., Ivankovic, M., Kelleher, C.T., Koskela, J., Rotach, P., Vietto, L. and Yrjänä, L. 2015. Pan-European strategy for genetic conservation of forest trees and establishment of a core network of dynamic conservation units. European Forest Genetic Resources Programme (EUFORGEN), Bioversity International, Rome, Italy.

Dufrêne E, Davi H, François C, Le Maire G, Le Dante V, Granier A, 2005. Modelling carbon and water cycles in a beech forest: Part I: Model description and uncertainty analysis on modelled NEE. Ecological Modelling 185: 407-436.

Eckert AJ, Maloney PE, Vogler DR, Jensen CE, Mix AD, Neale DB, 2015. Local adaptation at fine spatial scales: an example from sugar pine (Pinus lambertiana, Pinaceae). Tree Genetics \& Genomes 11: 42.

Eggermont H., Balian E., Azevedo J.M.N., Beumer V., Brodin T., Claudet J., Fady B., Grube M., Keune H., Lamarque P., Reuter K., Smith M., van Ham C., Weisser W.W., Le Roux X., 2015. Nature-based solutions: new influence for environmental management and research in Europe. GAIA - Ecological Perspectives for Science and Society 24(4), $243-248$.

Fady B, Cottrell J, Ackzell L, Alía R, Muys B, Prada A, González-Martínez SC, 2016. Forests and global change: what can genetics contribute to the major forest management and policy challenges of the twenty-first century? Regional Environmental Change 16(4), 927-939. Doi: 10.1007/s10113-015-0843-9.

Fréjaville T, Fady B, Kremer A, Ducousso A, Benito Garzón M, 2019. Inferring phenotypic plasticity and population responses to climate across tree species ranges using forest inventory data. Global Ecology and Biogeography 28: 1259-1271. https://doi.org/10.1111/geb.12930.

Gargiulo R, Saubin M, Rizzuto G, West B, Fay F, Kallow S, Trivedi C, 2019.Genetic diversity in British populations of Taxus baccata $L$.: Is the seedbank collection representative of the genetic variation in the wild? Biological Conservation 233: 289-297. https://doi.org/10.1016/j.biocon.2019.01.014

Gauzere J, Oddou-Muratorio S, Gay L, Klein EK, 2016. Partial genotyping at polymorphic markers can improve heritability estimates in sibling groups. Molecular Ecology Resources 16: 1340-1352

Gauzere J, Klein EK, Brendel O, Davi H, Oddou-Muratorio S, 2020. Microgeographic adaptation and the effect of pollen flow on the adaptive potential of a temperate tree species. New Phytologist 227 (2): 641-653

Hancock AM, Brachi B, Faure N, Horton MW, Jarymowycz LB, Sperone FG, Toomajian C, Roux F, Bergelson J, 2011. Adaptation to climate across the Arabidopsis thaliana genome. Science 333: 83-86 doi:10.1126/science.1209244

Hoban S, Kallow S, Trivedi C., 2018. Implementing a new approach to effective conservation of genetic diversity, with ash (Fraxinus excelsior) in the UK as a case study. Biological Conservation 225: 10-21, https://doi.org/10.1016/j.biocon.2018.06.017.

Hoban S, Stand A, 2015. Ex situ seed collections will benefit from considering spatial sampling design and species' reproductive biology. Biological Conservation 187: 182-191 https://doi.org/10.1016/j.biocon.2015.04.023

Hohenlohe PA, Phillips PC, Cresko WA, 2010. Using population genomics to detect selection in natural populations: key concepts and methodological considerations International Journal of Plant Science 171: 1059-1071 doi:10.1086/656306

Karger DN, Conrad O, Bohner J, Kawohl T, Kreft H, Soria-Auza RW, . . Kessler M, 2017. Climatologies at high resolution for the earth's land surface areas. Scientific Data, 4, 20. doi:10.1038/sdata.2017.122

Le Corre V, Kremer A, 2012. The genetic differentiation at quantitative trait loci under local adaptation Molecular Ecology 21: 1548-1566 doi:10.1111/j.1365-294X.2012.05479.x

Lefèvre F, Boivin T, Bontemps A, Courbet F, Davi H, Durand-Gillmann M, Fady B., Gauzere J., Gidoin C, Karam MJ, H, Oddou-Muratorio S, Pichot C, 2014. Considering evolutionary processes in adaptive forestry. Annals of Forest Science 71: 723-739; doi:10.1007/s13595-013-0272-1

Leimu R, Fischer M, 2008. A meta-analysis of local adaptation in plants. PLoS ONE, 3: e4010.

Lind BM, Friedline CJ, Wegrzyn JL, Maloney PE, Vogler DR, Neale DB, Eckert AJ, 2017. Water availability drives signatures of local adaptation in whitebark pine (Pinus albicaulis Engelm.) across fine spatial scales of the Lake Tahoe Basin, USA. Molecular Ecology 26: 3168-3185

Lind BM, Menon M, Bolte CE, Faske TM, Eckert AJ, 2018. The genomics of local adaptation in trees: Are we out of the woods yet? Tree Genetics \& Genomes 14 (2): 29 
Lloret F, Peñuelas J, Prieto P, Llorens L, Estiarte M, 2009. Plant community changes induced by experimental climate change: seedling and adult species composition. Perspectives in Plant Ecology Evolution and Systematics 11: 53- 63.

Lotterhos KE, Whitlock MC. The relative power of genome scans to detect local adaptation depends on sampling design and statistical method. Molecular Ecology 24(5):1031-1046. doi:10.1111/mec.13100

Martínez-Sancho E, Mateju L, Morganti S, Grefen C, Carvalho B, Dauphin B, Rellstab C, Gugerli F, Opgenoorth L, Heer K, Knutzen F, von Arx G, Valladares F, Cavers S, Fady B, Alia Miranda R, Aravanopoulos F, Avanzi C, Bagnoli F, Barbas E, Bastien C, Benavides R, Bernier F, Bodineau G, Bastias CC, Charpentier JP, Climent JM, Corréard M, Courdier F, Danusevicius D, Farsakoglou M, García del Barrio JM, Gilg O, González-Martínez SC, Gray A, Hartleitner C, Hurel A, Jouineau A, Kärkkäinen K, Kujula S, Labriola M., Lascoux M, Lefebvre M, Lejeune V, Liesebach M, Malliarou E, Mariotte N, Matesanz S, Myking T, Notivol E, Pakull B, Piotti A, Pringarbe M, Pyhajarvi T, Raffin A, Ramirez-Valiente JA, Ramskogler K, Robledo-Arnuncio J, Savolainen O, Schüler S, Semerikov V, Spanu I, Thévenet J, Tollefsrud MM, Turion N, Veisse D, Vendramin G, Villar M, Westin J, Fonti $P, 2019$. The GenTree Dendroecological Collection: tree-ring and wood density data from seven tree species across Europe. Scientific Data, 7(1): 1.

McGill BJ, Enquist BJ, Weiher E, Westoby M, 2006) Rebuilding community ecology from functional traits. Trends in Ecology and Evolution 21: 178-185.

McKinney GJ, Waples RK, Seeb LW, Seeb JE, 2017. Paralogs are revealed by proportion of heterozygotes and deviations in read ratios in genotyping-by-sequencing data from natural populations. Molecular Ecology Resources 17: 656-669 doi:10.1111/1755-0998.12613

Menon M, Bagley JC, Friedline C, Whipple AV, Schoettle AW, Leal-Saenz A, Wehenkel C, MolinaFreaner F, Flores-Renteria L, Gonzalez-Elizondo MS, Sniezko RA, Cushman SA, Waring KM, Eckert AJ, 2018. The role of hybridization during ecological divergence of southwestern white pine (Pinus strobiformis) and limber pine ( $P$. flexilis). Molecular Ecology 27, 1245-1260

Milesi P, Berlin M, Chen J, Orsucci M, Li L, Jansson G, Karlsson B, Lascoux M, 2019. Assessing the potential for assisted gene flow using past introduction of Norway spruce in southern Sweden: Local adaptation and genetic basis of quantitative traits in trees. Evolutionary Applications 12: 1946-1959 doi:10.1111/eva.12855

Mosca E, Cruz F, Gómez-Garrido J, Bianco L, Rellstab C, Brodbeck S, Csilléry K, Fady B, Fladung M, Fussi B, Gömöry D, González-Martínez SC, Grivet D, Gut M, Hansen OK, Heer K, Kaya Z, Krutovsky KV, Kersten B, Liepelt S, Opgenoorth L, Sperisen C, Ullrich KK, Vendramin GG, Westergren M, Ziegenhagen B, Alioto T, Gugerli F, Heinze B, Höhn M, Troggio M, Neale DB, 2019. A Reference Genome Sequence for the European Silver Fir (Abies alba Mill.): A Community-Generated Genomic Resource. G3: Genes, Genomes, Genetics, 9(7), 2039-2049 (https://doi.org/10.1534/g3.119.400083).

Pennisi E, 2020. Massive effort to document the genetics of European forests bears fruit. Science, Jan 27, 2020 (doi:10.1126/science.abb0632).

Plumer B, Popovich N, 2018. The World Still Isn't Meeting Its Climate Goals. The New York Times, Dec. 7, 2018. https://www.nytimes.com/interactive/2018/12/07/climate/world-emissions-parisgoals-not-on-track.html.

Reichstein M, Michael B, Mahecha MD, Kattge J, Baldocchi DD, 2014. Linking plant and ecosystem functional biogeography. Proceedings of the National Academy of Sciences USA, 111,13697-702.

Rellstab C, Gugerli F, Eckert AJ, Hancock AM, Holderegger R, 2015. A practical guide to environmental association analysis in landscape genomics. Molecular Ecology 24: 4348-4370 doi:10.1111/mec.13322

Reutimann O, Gugerli F, Rellstab C, 2020. A species-discriminatory single-nucleotide polymorphism set reveals maintenance of species integrity in hybridizing European white oaks (Quercus spp.) despite high levels of admixture. Annals of Botany, 125(4), 663-676. doi:10.1093/aob/mcaa001

Richardson JL, Urban MC, Bolnick DI, Skelly DK, 2014. Microgeographic adaptation and the spatial scale of evolution. Trends in Ecology and Evolution 29(3): 165-76

Savolainen O, Lascoux M, Merilä J, 2013. Ecological genomics of local adaptation. Nature Review Genetics 14: 807-820 doi:10.1038/nrg3522.

Schelhaas MJ, Nabuurs GJ, Hengeveld G, Reyer C, Hanewinkel M, Zimmermann NE, Cullmann D, 2015. Alternative forest management strategies to account for climate change-induced productivity and species suitability changes in Europe. Regional Environmental Change, 15(8): 1581-1594. https://doi.org/10.1007/s10113-015-0788-z 
Truffaut L, Chancerel E, Ducousso A, Dupouey JL, Badeau V, Ehrenmann F, Kremer A, 2017. Finescale species distribution changes in a mixed oak stand over two successive generations New Phytologist 215:126-139. https://doi.org/10.1111/nph.14561.

Vinceti B., Manica M., Lauridsen N., Verkerk P.J., Lindner M., Fady B., 2020. Managing forest genetic resources as a strategy to adapt forests to climate change: perceptions of European forest owners and managers. European Journal of Forest Research, 1-13. https://doi.org/10.1007/s10342-02001311-6.

Yeaman S, 2015. Local adaptation by alleles of small effect. The American Naturalist, 186: S74-S89.

\section{Annex 1: GenTree/Stakeholders' consultation - University of Avignon, $30 / 1 / 2020$}

Download the report:

http://www.gentree-h2020.eu/fileadmin/Gentree-

uploads/documents/GenTree stakeholders consultation 30Jan2020 report short fi $\underline{\text { nal.pdf }}$

\section{Annex 2: links to talks and posters presented at the conference "\#rescueforests: Genetics to the rescue - Managing forests sustainably in a changing world", held in Avignon (France) January 2020.}

Talks: All conference talks were filmed, professionally edited and the videos made available on two platforms:

https://www.youtube.com/channel/UCAht9RAZ7YrrUYHMa7AuVpg/videos

and

https://www.canal-

u.tv/producteurs/universite $d$ avignon et des pays de vaucluse/colloque/gentree inrae.

Posters: Conference posters are available for download at (and see full list below): https://colloque.inrae.fr/confgentree2020/The-Conference/Posters.

List of posters that were presented at the conference and were provided with their pdf file, organized by session and alphabetically with the first name of presenter.

\begin{tabular}{|c|c|c|c|c|c|c|}
\hline Session name & Poster title & Web link & Gender & First name & Last Name & Country \\
\hline $\begin{array}{l}\text { Session 1: } \\
\text { GENOME \& } \\
\text { ENVIRONMENT }\end{array}$ & $\begin{array}{l}\text { An automated } \\
\text { bioinformatics pipeline: } \\
\text { from importing SNP } \\
\text { data to estimating } \\
\text { population genetic } \\
\text { parameters }\end{array}$ & $\frac{\frac{\text { Poster }}{\text { Farsakogloupdf - }}}{\underline{915 \mathrm{kB}}}$ & Ms & $\begin{array}{l}\text { Anna- } \\
\text { Maria }\end{array}$ & Farsakoglou & Greece \\
\hline $\begin{array}{l}\text { Session 1: } \\
\text { GENOME \& } \\
\text { ENVIRONMENT }\end{array}$ & $\begin{array}{l}\text { Predicting the adaptive } \\
\text { landscape of European } \\
\text { common beech (Fagus } \\
\text { sylvatica) in the face of } \\
\text { climate change }\end{array}$ & $\begin{array}{l}\frac{\underline{\text { Poster }}}{\text { Schumanpdf - }} \\
\underline{24.2 \mathrm{MB}}\end{array}$ & Ms & Meredith & Schuman & Switzerland \\
\hline
\end{tabular}




\begin{tabular}{|c|c|c|c|c|c|c|}
\hline $\begin{array}{l}\text { Session 1: } \\
\text { GENOME \& } \\
\text { ENVIRONMENT }\end{array}$ & $\begin{array}{l}\text { GenTree Upside Down: } \\
\text { Local adaptation of } \\
\text { Nothofagus pumilio } \\
\text { along environmental } \\
\text { gradients in the Andes }\end{array}$ & $\begin{array}{l}\text { Poster Sekelypdf - } \\
\underline{4.5 \mathrm{MB}}\end{array}$ & Ms & Jill & Sekely & Germany \\
\hline $\begin{array}{l}\text { Session 1: } \\
\text { GENOME \& } \\
\text { ENVIRONMENT }\end{array}$ & $\begin{array}{l}\text { Spatial genetic } \\
\text { differentiation in Picea } \\
\text { glauca stands in Alaska }\end{array}$ & $\begin{array}{l}\frac{\text { Poster }}{\text { Zachariaspdf }-1.3} \\
\underline{\text { MB }}\end{array}$ & Ms & Melanie & Zacharias & Germany \\
\hline $\begin{array}{l}\text { Session 2: LOCAL } \\
\text { ADAPTATION }\end{array}$ & $\begin{array}{l}\text { Selection gradients } \\
\text { under two contrasting } \\
\text { environments in } \\
\text { Maritime pine }\end{array}$ & $\begin{array}{l}\frac{\text { Poster Alia }}{\text { selection }} \\
\text { gradientspdf - } 1.9 \\
\underline{\text { MB }}\end{array}$ & $\mathrm{Mr}$ & Ricardo & Alia & Spain \\
\hline $\begin{array}{l}\text { Session 2: LOCAL } \\
\text { ADAPTATION }\end{array}$ & $\begin{array}{l}\text { Transcriptome analysis } \\
\text { reveals different } \\
\text { physiological } \\
\text { mechanisms of drought } \\
\text { avoidance between the } \\
\text { relict conifers Abies } \\
\text { pinsapo and Cedrus } \\
\text { atlantica }\end{array}$ & $\begin{array}{l}\text { Poster Cobo- } \\
\underline{\text { Simonpdf }-1.9} \\
\underline{\text { MB }}\end{array}$ & Ms & Irene & Cobo-Simón & Spain \\
\hline $\begin{array}{l}\text { Session 2: LOCAL } \\
\text { ADAPTATION }\end{array}$ & $\begin{array}{l}\text { Genome-wide } \\
\text { association study of } \\
\text { drought responses in } \\
\text { Swiss Fagus sylvatica }\end{array}$ & $\begin{array}{l}\text { Poster deWittepdf } \\
-10.8 \mathrm{MB}\end{array}$ & Ms & Lucienne & de Witte & Switzerland \\
\hline $\begin{array}{l}\text { Session 2: LOCAL } \\
\text { ADAPTATION }\end{array}$ & $\begin{array}{l}\text { GENWOOD - } \\
\text { Exploring the genomic } \\
\text { basis of wood anatomy }\end{array}$ & $\underline{\text { Poster Fontipdf - }}$ & $\mathrm{Mr}$ & Patrick & Fonti & Switzerland \\
\hline $\begin{array}{l}\text { Session 2: LOCAL } \\
\text { ADAPTATION }\end{array}$ & $\begin{array}{l}\text { What are the } \\
\text { physiological processes } \\
\text { involved in tree } \\
\text { reproduction and how } \\
\text { climate change impacts } \\
\text { it? }\end{array}$ & $\begin{array}{l}\text { Poster Journepdf - } \\
\underline{3.3 \mathrm{MB}}\end{array}$ & $\mathrm{Mr}$ & Valentin & Journe & France \\
\hline $\begin{array}{l}\text { Session 2: LOCAL } \\
\text { ADAPTATION }\end{array}$ & $\begin{array}{l}\text { The last trees-survivors: } \\
\text { a pilot study of } \\
\text { characteristics of Picea } \\
\text { abies surviving Ips } \\
\text { typograpus outbreak }\end{array}$ & $\begin{array}{l}\frac{\text { Poster }}{\text { Korolyovapdf - }} \\
\underline{1.2 \mathrm{MB}}\end{array}$ & Ms & Nataliya & Korolyova & $\begin{array}{l}\text { Czech } \\
\text { Republic }\end{array}$ \\
\hline $\begin{array}{l}\text { Session 2: LOCAL } \\
\text { ADAPTATION }\end{array}$ & $\begin{array}{l}\text { Signs of epigenetic } \\
\text { regulation of spring } \\
\text { phenology, } \\
\text { photosynthesis and } \\
\text { drought tolerance in } \\
\text { Abies nordmanniana } \\
\text { emblings }\end{array}$ & $\begin{array}{l}\text { Poster Lobopdf - } \\
\underline{826.8 \mathrm{kB}}\end{array}$ & $\mathrm{Mr}$ & Albin & Lobo & Denmark \\
\hline $\begin{array}{l}\text { Session 2: LOCAL } \\
\text { ADAPTATION }\end{array}$ & $\begin{array}{l}\text { Variation of the serotiny } \\
\text { levels in Pinus } \\
\text { halepensis according to } \\
\text { the fire reccurence: } \\
\text { genome-wide } \\
\text { association study }\end{array}$ & $\begin{array}{l}\text { Poster Romeropdf } \\
-1.9 \mathrm{MB}\end{array}$ & $\mathrm{Mr}$ & Bastien & Romero & France \\
\hline $\begin{array}{l}\text { Session 2: LOCAL } \\
\text { ADAPTATION }\end{array}$ & $\begin{array}{l}\text { Straightening the } \\
\text { crooked: unveiling the } \\
\text { adaptive implications of } \\
\text { tree stem postural } \\
\text { control }\end{array}$ & $\begin{array}{l}\frac{\text { Poster Sierra-de- }}{\text { Gradopdf }-909.3} \\
\underline{\mathrm{kB}}\end{array}$ & Ms & Rosario & $\begin{array}{l}\text { Sierra-de- } \\
\text { Grado }\end{array}$ & Spain \\
\hline
\end{tabular}




\begin{tabular}{|c|c|c|c|c|c|c|}
\hline $\begin{array}{l}\text { Session 2: LOCAL } \\
\text { ADAPTATION }\end{array}$ & $\begin{array}{l}\text { Solving a puzzle of half } \\
\text { a million rings }- \text { How } \\
\text { did we measure the tree- } \\
\text { ring width series from } \\
\text { the H2020 GenTree } \\
\text { project? }\end{array}$ & $\begin{array}{l}\frac{\text { Poster }}{\text { Slamovapdf }-1.8} \\
\underline{\underline{\text { MB }}}\end{array}$ & Ms & Lenka & Slámová & Switzerland \\
\hline $\begin{array}{l}\text { Session 2: LOCAL } \\
\text { ADAPTATION }\end{array}$ & $\begin{array}{l}\text { Local adaptation in } \\
\text { silver birch growth and } \\
\text { stem quality traits in } \\
\text { Latvia }\end{array}$ & $\begin{array}{l}\text { Poster Zeltinspdf - } \\
\underline{551.9 \mathrm{kB}}\end{array}$ & $\mathrm{Mr}$ & Pauls & Zeltins & Latvia \\
\hline $\begin{array}{l}\text { Session 3: } \\
\text { CONSERVING } \\
\text { and USE }\end{array}$ & $\begin{array}{l}\text { Simulation of tree } \\
\text { breeding through open } \\
\text { pollinated offspring via } \\
\text { birch as a case study. }\end{array}$ & $\begin{array}{l}\text { Poster } \\
\text { Abrahamssonpdf - } \\
\underline{1.7 \mathrm{MB}}\end{array}$ & Ms & Sara & Abrahamsson & Sweden \\
\hline $\begin{array}{l}\text { Session 3: } \\
\text { CONSERVING } \\
\text { and USE }\end{array}$ & $\begin{array}{l}\text { Comparative analysis of } \\
\text { genetic diversity in } \\
\text { natural and breeding } \\
\text { populations }\end{array}$ & $\begin{array}{l}\text { Poster Alia } \\
\underline{\text { Breedingpdf }-1.4} \\
\underline{\text { MB }}\end{array}$ & $\mathrm{Mr}$ & Ricardo & Alia & Spain \\
\hline $\begin{array}{l}\text { Session 3: } \\
\text { CONSERVING } \\
\text { and USE }\end{array}$ & $\begin{array}{l}\text { Characterization of the } \\
\text { European conservation } \\
\text { network for } 12 \text { forest } \\
\text { tree species: findings } \\
\text { and perspectives }\end{array}$ & $\begin{array}{l}\frac{\text { Poster }}{\text { Aravanopoulospdf }} \\
\underline{-1.8 \mathrm{MB}}\end{array}$ & $\mathrm{Mr}$ & Filippos & Aravanopoulos & Greece \\
\hline $\begin{array}{l}\text { Session 3: } \\
\text { CONSERVING } \\
\text { and USE }\end{array}$ & $\begin{array}{l}\text { Incorporating } \\
\text { phylogeography for } \\
\text { modelling the } \\
\text { distribution of the carob } \\
\text { tree (Ceratonia siliqua, } \\
\text { Leguminosae) in future } \\
\text { climate change }\end{array}$ & $\begin{array}{l}\text { Poster Baumelpdf } \\
-7.6 \mathrm{MB}\end{array}$ & $\mathrm{Mr}$ & Alex & Baumel & France \\
\hline $\begin{array}{l}\text { Session 3: } \\
\text { CONSERVING } \\
\text { and USE }\end{array}$ & $\begin{array}{l}\text { Evolution in real time: } \\
\text { assessing genetic } \\
\text { change in Aleppo pine } \\
\text { through a selection } \\
\text { experiment }\end{array}$ & $\begin{array}{l}\text { Poster Climentpdf } \\
\underline{-2.3 \mathrm{MB}}\end{array}$ & $\mathrm{Mr}$ & Jose & Climent & Spain \\
\hline $\begin{array}{l}\text { Session 3: } \\
\text { CONSERVING } \\
\text { and USE }\end{array}$ & $\begin{array}{l}\text { National programme for } \\
\text { the Conservation of } \\
\text { Forest Genetic } \\
\text { resources in France }\end{array}$ & $\begin{array}{l}\frac{\text { Poster }}{\text { Desgrouxpdf }-2.1} \\
\underline{\underline{M B}}\end{array}$ & Ms & Aurore & Desgroux & France \\
\hline $\begin{array}{l}\text { Session 3: } \\
\text { CONSERVING } \\
\text { and USE }\end{array}$ & $\begin{array}{l}\text { Dynamic of } \\
\text { fructification and } \\
\text { conservation of genetic } \\
\text { resources of } \\
\text { Pedunculate oak } \\
\text { (Quercus robur L.) and } \\
\text { European beech (Fagus } \\
\text { sylvatica L.) in light of } \\
\text { climate changes }\end{array}$ & $\frac{\frac{\text { Poster }}{\text { Gavranovicpdf - }}}{\underline{1.7 \mathrm{MB}}}$ & Ms & Anđelina & Gavranović & Croatia \\
\hline $\begin{array}{l}\text { Session 3: } \\
\text { CONSERVING } \\
\text { and USE }\end{array}$ & $\begin{array}{l}\text { Development of a new } \\
\text { tool (4TREE) for } \\
\text { adapted genome } \\
\text { selection in European } \\
\text { tree species }\end{array}$ & $\begin{array}{l}\frac{\text { Poster }}{\text { Guilbaudpdf }-1.8} \\
\underline{\text { MB }}\end{array}$ & Ms & Romane & Guilbaud & France \\
\hline $\begin{array}{l}\text { Session 3: } \\
\text { CONSERVING } \\
\text { and USE }\end{array}$ & $\begin{array}{l}\text { Survey results show } \\
\text { positive perceptions of } \\
\text { adaptive tree breeding }\end{array}$ & $\begin{array}{l}\text { Poster Oraziopdf - } \\
\underline{271.6 \mathrm{kB}}\end{array}$ & $\mathrm{Mr}$ & Christophe & Orazio & France \\
\hline
\end{tabular}




\begin{tabular}{|c|c|c|c|c|c|c|}
\hline $\begin{array}{l}\text { Session 3: } \\
\text { CONSERVING } \\
\text { and USE }\end{array}$ & $\begin{array}{l}\text { Testing a pan-European } \\
\text { minimal approach for } \\
\text { genetic monitoring in } \\
\text { beech and poplar }\end{array}$ & $\begin{array}{l}\text { Poster Pakullpdf - } \\
\underline{900.4 \mathrm{kB}}\end{array}$ & Ms & Birte & Pakull & Germany \\
\hline $\begin{array}{l}\text { Session 3: } \\
\text { CONSERVING } \\
\text { and USE }\end{array}$ & $\begin{array}{l}\text { Genetic species } \\
\text { assignment reveals } \\
\text { considerable levels of } \\
\text { admixture in three } \\
\text { interfertile European } \\
\text { white oak species }\end{array}$ & $\frac{\frac{\text { Poster }}{\text { Reutimannpdf - }}}{\underline{1.1 \mathrm{MB}}}$ & $\mathrm{Mr}$ & Oliver & Reutimann & Switzerland \\
\hline $\begin{array}{l}\text { Session 3: } \\
\text { CONSERVING } \\
\text { and USE }\end{array}$ & $\begin{array}{l}\text { Balancing genomic } \\
\text { selection and genetic } \\
\text { diversity in the breeding } \\
\text { program of Populus } \\
\text { nigra }\end{array}$ & $\begin{array}{l}\text { Poster Tiretpdf - } \\
\underline{1.4 \mathrm{MB}}\end{array}$ & $\mathrm{Mr}$ & Mathieu & Tiret & Sweden \\
\hline $\begin{array}{l}\text { Session 3: } \\
\text { CONSERVING } \\
\text { and USE }\end{array}$ & $\begin{array}{l}\text { The assessment of the } \\
\text { genetic resources of } \\
\text { black poplar (Populus } \\
\text { nigra L.) populations } \\
\text { from the Oder valley - } \\
\text { implications for the } \\
\text { conservation of the } \\
\text { species gene pool in } \\
\text { Poland }\end{array}$ & $\begin{array}{l}\frac{\text { Poster }}{\text { Wójkiewiczpdf - }} \\
\underline{8.3 \mathrm{MB}}\end{array}$ & $\mathrm{Mr}$ & Błażej & Wójkiewicz & Poland \\
\hline $\begin{array}{l}\text { Session 4: } \\
\text { EVOLUTIONARY } \\
\text { MANAGEMENT }\end{array}$ & $\begin{array}{l}\text { Fingerprinting of } \\
\text { genetic diversity as a } \\
\text { tool for conservation } \\
\text { management of forest } \\
\text { genetic resources in the } \\
\text { peripheral island } \\
\text { endemic tree of Cedrus } \\
\text { brevifolia (Hook f.) } \\
\text { Henry. }\end{array}$ & $\begin{array}{l}\text { Poster Eliadespdf } \\
\underline{-1.8 \mathrm{MB}}\end{array}$ & $\mathrm{Mr}$ & $\begin{array}{l}\text { Nicolas- } \\
\text { George }\end{array}$ & Eliades & Cyprus \\
\hline $\begin{array}{l}\text { Session 4: } \\
\text { EVOLUTIONARY } \\
\text { MANAGEMENT }\end{array}$ & $\begin{array}{l}\text { Proposal of a network } \\
\text { of conservation units of } \\
\text { forest genetic resources } \\
\text { in Spain. The } \\
\text { importance of } \\
\text { GENTREE sampling } \\
\text { points as network } \\
\text { nodes. }\end{array}$ & $\begin{array}{l}\text { Poster García del } \\
\underline{\text { Barriopdf }-820.4} \\
\underline{\mathrm{kB}}\end{array}$ & $\mathrm{Mr}$ & José M. & $\begin{array}{l}\text { García del } \\
\text { Barrio }\end{array}$ & España \\
\hline $\begin{array}{l}\text { Session 4: } \\
\text { EVOLUTIONARY } \\
\text { MANAGEMENT }\end{array}$ & $\begin{array}{l}\text { Natural and artificial } \\
\text { selection on seedling } \\
\text { traits in Scots pine }\end{array}$ & $\underline{\text { Poster Kujalapdf - }}$ & Ms & Sonja & Kujala & Finland \\
\hline $\begin{array}{l}\text { Session 4: } \\
\text { EVOLUTIONARY } \\
\text { MANAGEMENT }\end{array}$ & $\begin{array}{l}\text { Genetic variation in } \\
\text { Taxus baccata L.: a case } \\
\text { study supporting } \\
\text { Poland's protection and } \\
\text { restoration program }\end{array}$ & $\begin{array}{l}\frac{\text { Poster }}{\text { Litkowiecpdf - }} \\
\underline{1.2 \mathrm{MB}}\end{array}$ & Ms & Monika & Litkowiec & Poland \\
\hline $\begin{array}{l}\text { Session 4: } \\
\text { EVOLUTIONARY } \\
\text { MANAGEMENT }\end{array}$ & $\begin{array}{l}\text { Assessment of the } \\
\text { impact of land use } \\
\text { change on ecological } \\
\text { security }\end{array}$ & $\begin{array}{l}\frac{\text { Poster }}{\text { Polevshikovapdf - }} \\
\underline{\underline{5.6 \mathrm{MB}}}\end{array}$ & Ms & Iuliia & Polevshchikova & Russia \\
\hline
\end{tabular}

